\title{
Histochemical Demonstration of Glycogen Synthetase in the Normal Human Epidermis
}

\author{
Yoichiro Sasai \\ Department of Dermatology (Prof. Y. Takahashi), \\ Tohoku University School of Medicine, Sendai
}

\begin{abstract}
A method for histochemical demonstration of glycogen synthetase activity in the human epidermis was examined. For microscopically discerning glycogen synthetase reaction at the tissue site, a concentration of uridine diphosphate glucose about 4 times that in the Takeuchi and Glenner's substrate medium was required. With the increase of glucose-6-phosphate concentration, the incubation time necessary for the appearance of reaction was shortened. This effect was most prominent at $\mathrm{pH}$ 9.0. Based on these results, the optimum composition of the substrate medium was described.
\end{abstract}

In general, glycogen synthesis proceeds through uridine diphosphate glucosea-glucan glucosyltransferase (glycogen synthetase), and glycogen degradation occurs through phosphorylase. ${ }^{1}$ And this is true of epidermal glycogen. ${ }^{2}$ Thus, in discussing the localization of glycogen in tissue sections, it is essential to investigate glycogen synthetase and phosphorylase.

In the physiological state, the human epidermis is usually free of glycogen demonstrable with ordinary histochemical methods. When glycogen does exist, it is often found in the cells of the upper stratum malpighii. Several workers ${ }^{3-8}$ surveyed the localization and the related concentrations of phosphorylase in the epidermis, concluding that there was no correlation between enzyme activity and glycogen distribution. However, no report has been presented on glycogen synthetase activity in the normal human epidermis. The purpose of this paper is to describe a reliable method for such demonstration.

\section{Materials and Methods}

For the demonstration of glycogen synthetase reaction, Takeuchi and Glenner's method $^{9}$ was used as the principal technique.

Biopsy skin speeimens, which were removed from lower extremities of healthy males ranging from 25 to 35 years of age, were frozen in a Dewar's vessel containing liquid nitrogen. Serial sections were made at $20 \mu$ in a cryostat maintained at $-20^{\circ} \mathrm{C}$ and mounted on coverslips. They were dried for 2 minutes in air and incubated at $57^{\circ} \mathrm{C}$ for the predetermined periods in Coplin jars, each of which contained $20 \mathrm{mg}$ of glycogen, $20 \mathrm{mg}$ of ethylenediamine-

Received for publication, May 7, 1968 
tetraacetic acid, $10 \mathrm{ml}$ of $0.2 \mathrm{M}$ Tris buffer, $14 \mathrm{ml}$ of distilled water, $1 \mathrm{ml}$ ethanol and uridine diphosphate glucose in a final concentration from 1.0 to $36.0 \mathrm{mg}$ per $\mathrm{ml}$. At the end of each incubation period some sections were taken out, and after 5 minutes' fixa. tion in ethanol, they were immersed for 3 minutes in Lugol's iodine-iodide solution, which was diluted 10 times with distilled water. They were dried in air and mounted with glycerin. The observations of the slides thus prepared were carried out by continuous use of the same binocular microscope, and the time when a positive reaction was first discernible in the malpighian cells was recorded as the end point of glycogen synthetase reaction on a given slide. The control substrate solution contained no uridine diphosphate glucose. All the control tests were negative.

The disodium salt of uridine diphosphate glucose was obtained from C.F. Böhringer \& Söhne Gmbh, Germany. The disodium salt of D-glucose-6-phosphate and that of adenosine triphosphate were supplied by Sigma Chem. Co., U.S.A. $\alpha$-Amylase was obtained from Nutritional Biochem. Co., U.S.A. Glycogen and the disodium salt of ethylenediaminetetraacetic acid were obtained from Wako Pure Chem. Indust., Japan.

\section{OBSERVATIONS}

\section{1) Relation of the time of appearance of glycogen synthetase reaction with substrate concentration}

Incubation was performed at $\mathrm{pH}$ 7.4. Glycogen synthetase reaction appeared at 120 minutes of incubation in a substrate concentration of $36 \mathrm{mg}$ per $\mathrm{ml}$ or at 150 minutes in $24 \mathrm{mg}$ per $\mathrm{ml}$ (Table 1). In a substrate concentration of $12 \mathrm{mg}$ or less per $\mathrm{ml}$, no reaction was found.

TABLE 1. Relation of the time of appearance of glycogen synthelase reaction with substrate concentration at $p H \% .4$

\begin{tabular}{c|c|c|c|c|c|c|c}
\hline \multirow{2}{*}{$\begin{array}{c}\text { Substrate } \\
\text { concentraton } \\
\text { (mg per ml) }\end{array}$} & \multicolumn{7}{|c}{ Time of incubation (min) } \\
\cline { 2 - 8 } & 30 & 60 & 90 & 120 & 150 & 180 \\
\hline 36 & - & - & - & + & + & + \\
24 & - & - & - & - & + & + \\
12 & - & - & - & - & - & - \\
6 & - & - & - & - & - & - \\
3 & - & - & - & - & - & - \\
1 & - & - & - & - & - & -
\end{tabular}

\section{2) Effect of $p H$}

The effect of $\mathrm{pH}$ on the reaction was studied in three experiments using Tris or glycin buffer of $\mathrm{pH} 7.0$ to 9.8 . In the first experiment, the substrate solution consisted of the same components as described above. The second experiment was carried out with a substrate solution to which glucose-6-phosphate was added in a concentration of $6 \mathrm{mg}$ per $\mathrm{ml}$. In the third experiment, glycine buffer was employed in place of Tris buffer in the second experiment.

In the first experiment, glycogen synthetase reaction appeared at 150 minutes of incubation in a substrate concentration of $24 \mathrm{mg}$ per $\mathrm{ml}$ at $\mathrm{pH} 7.2$ to 7.6 . In the second experiment, however, the optimum $\mathrm{pH}$ was shifted to a more alkaline range. 
At $\mathrm{pH} 8.8$ to 9.2 , glycogen synthetase reaction appeared at 90 minutes of incubation in a substrate concentration of $24 \mathrm{mg}$ per $\mathrm{ml}$. The replacement of Tris buffer with glycine buffer yielded no conspicuous effect on the reaction.

\section{3) Effect of glucose-6-phosphate concentration}

Glucose-6-phosphate, in a final concentration of $1,5,10,20,40$ or $75 \mathrm{mg}$ per $\mathrm{ml}$, was added to a parallel series of substrate solutions at $\mathrm{pH} 9.0$.

With the increase of glucose-6-phosphate concentration, the incubation time necessary for the appearance of the reaction was shortened. At concentrations of 20 and $40 \mathrm{mg}$ per ml, this effect was most prominent (Tables 2 and 3).

TABLE 2. Relation of the time of appearance of glycogen synthetase reaction with substrate concentration in the presence of glucose-

6-phosphate in $5 \mathrm{mg}$ per $\mathrm{ml}$ at $\mathrm{pH} 9.0$

\begin{tabular}{|c|c|c|c|c|c|c|}
\hline \multirow{2}{*}{$\begin{array}{c}\text { Substrate } \\
\text { concentration } \\
\text { (mg per ml) }\end{array}$} & \multicolumn{6}{|c|}{ Time of incubation (min) } \\
\hline & 30 & 60 & 90 & 120 & 150 & 180 \\
\hline 36 & - & - & + & + & + & + \\
\hline 24 & - & - & - & + & + & + \\
\hline 12 & - & - & - & - & + & + \\
\hline 6 & - & - & - & - & - & - \\
\hline 3 & - & - & - & - & - & - \\
\hline 1 & - & $\cdots$ & - & - & - & - \\
\hline
\end{tabular}

TABLE 3. Relation of the time of apperance of glycogen synthelase reaction with substrate concentration in the presence of glucose. 6-phosphate in $20 \mathrm{mg}$ per ml at pH 9.0

\begin{tabular}{c|c|c|c|c|c|c|c}
\hline $\begin{array}{c}\text { Substrate } \\
\text { concentration }\end{array}$ & \multicolumn{7}{|c}{ Time of incubation (min) } \\
(mg per ml) & 30 & 60 & 90 & 120 & 150 & 180 \\
36 & - & - & + & + & + & + & + \\
24 & - & - & + & + & + & + \\
12 & - & - & + & + & + & + \\
6 & - & - & - & + & + & + \\
3 & - & - & - & - & - & - \\
1 & - & - & - & - & - & -
\end{tabular}

4) Effect of adenosine triphosphate, magnesium chloride and adenosine-3',5'-cyclic phosphate

A series of substrate solutions containing glucose-6-phosphate in a final concentration of $40 \mathrm{mg}$ per $\mathrm{ml}$ was employed. Incubation was carried out at $\mathrm{pH} 9.0$.

In the absence of ethylenediaminetetraacetic acid, glycogen synthetase reaction appeared at 150 minutes of incubation in a substrate concentration of $24 \mathrm{mg}$ per $\mathrm{ml}$. The addition of adenosine triphosphate $(2 \mathrm{mM})$, magnesium chloride $(4 \mathrm{mM})$ and adenosine- $3^{\prime}, 5^{\prime}$-cyclic phosphate $(1 \mathrm{mM})$ hardly affected the incubation time neccessary for reaching the reaction end point. 


\section{5) Identification of reaction product}

In this experiment, the substrate solution was composed of $300 \mathrm{mg}$ of uridine diphosphate glucose, $500 \mathrm{mg}$ of glucose-6-phosphate, $20 \mathrm{mg}$ of glycogen, $20 \mathrm{mg}$ of ethylenediaminetetraacetic acid, $10 \mathrm{ml}$ of $0.2 \mathrm{M}$ Tris buffer $(\mathrm{pH} \mathrm{9.0)}, 14 \mathrm{ml}$ of distilled water and of $1 \mathrm{ml}$ of ethanol. The $\alpha$-amylase solution was composed of $10 \mathrm{mg}$ of $\alpha$-amylase, $20 \mathrm{ml}$ of distilled water and $10 \mathrm{ml}$ of $0.2 \mathrm{M}$ acetate buffer $(\mathrm{pH}$ $5.4)$, while the control solution lacked only $a$-amylase. The serial sections were incubated in the substrate solution for 120 minutes at $37^{\circ} \mathrm{C}$, and then immersed in the amylase solution for 15 minutes at $37^{\circ} \mathrm{C}$. The reaction product was completely digested.

\section{Discussion}

In 1960, Takeuchi and Glenner, ${ }^{9}$ and Wegmann, Verne and Guha ${ }^{10}$ reported on the histochemical demonstration of the pathway for polysaccharide synthesis from uridine diphosphate glucose by the use of a technique similar to that of the method described by Takeuchi and Kuriaki11 for phosphorylase. The product from uridine diphosphate glucose in tissue sections under the conditions of this technique was stained red-brown with iodine, digested completely by $\alpha$-amylase and incompletely by $\beta$-amylase. Thus, it was thought that the synthesis of red-brown stained polysaccharide from uridine diphosphate glucose in tissue sections seemed to depend not only on glycogen synthetase but in part on the activity of a branching enzyme. Subsequently, Takeuchi and Glenner ${ }^{12}$ introduced glucose-6-phosphate, ethanol and ethylenediaminetetraacetic acid into the substrate solution and found these additions enhanced the reaction considerably. According to them, ethanol facilitates the precipitation of synthesized polysaccharide and impedes the branching enzyme activity, and the effect of ethylenediaminetetraacetic acid is attributed to its chelation of inhibitory ions. Working with this substrate medium, they successfully demonstrated enzyme activity in fresh frozen sections of various organs of rat and rabbit, with the exception of the epidermis. In general, the rate of conversion of the substrate to the products of the reaction is determined by that of the enzyme-substrate complex to reaction products. Since the rate of substrate penetration to tissue sections depends upon the substrate concentration, the amount of the enzyme taking part in the reaction also is dependent upon the substrate concentration. According to Adachi, ${ }^{2}$ and Halprin and Ohkawara, ${ }^{\mathbf{3}}$ the g]ycogen synthetase activity in the epidermis is lower than that in other tissues. Therefore, it is not surprising that histochemical demonstration of the glycogen synthetase activity in the normal human epidermis requires several times the amount of substrate contained in the Takeuchi and Glenner's substrate medium.

Biochemical data have indicated that there are two forms of glycogen synthetase activity, one of which is $D$ form which requires glucose-6-phosphate as a cofactor for the activity, and the other is I form which assumes activity without this cofactor. ${ }^{14.15}$ These two forms of enzyme activity are interconvertible. The 
conversion of the $\mathrm{D}$ to the I form is stimulated by sulfhydryl reagent. The reverse conversion of the $\mathrm{I}$ to the $\mathrm{D}$ form is obtained in the presence of adenosine triphosphate and $\mathrm{Mg}^{++}$, and accelerated by adenosine- $3^{\prime}, 5^{\prime}$-cyclic phosphate. On the other hand, Steiner, Younger and King ${ }^{16}$ observed that the optimum $\mathrm{pH}$ shifted to a more alkaline range by the addition of glucose-6-phosphate to the substrate solution. In the present study, the incubation time necessary for the appearance of reaction was shortened with the increase of glucose-6-phosphate concentration, and this effect was most prominent at $\mathrm{pH} 8.8$ to 9.2. Also, the addition of adenosine triphosphate, magnesium chloride and adenosine- $3^{\prime}, 5^{\prime}$-cyclic phosphate to the substrate solution hardly affected the reaction. These facts seem to suggest that the epidermal glycogen synthetase is largely $\mathrm{D}$ form.

From these data, the following composition is to be recommended for demonstration of epidermal glycogen synthetase activity: $300 \mathrm{mg}$ of uridine diphosphate glucose, $500 \mathrm{mg}$ of glucose-6-phosphate, :0 $\mathrm{mg}$ of glycogen, $20 \mathrm{mg}$ of ethylenediaminetetraacetic acid, $10 \mathrm{ml}$ of $0.2 \mathrm{M}$ Tris buffer ( $\mathrm{pH} \mathrm{9.0),} 14 \mathrm{ml}$ of distilled water and $1 \mathrm{ml}$ of ethanol.

\section{References}

1) Stetten, D., Jr. \& Stetten, M.R. Glycogen metabolism. Physiol. Rev., 1960, 40, 505537.

2) Adachi, K. Metabolism of glycogen in the skin and the effect of X-rays. J. invest. Derm., 1961, 37, 381-395.

3) Braun-Falco, $O$. Histochemische und morphologische Studien an normaler und pathologisch veränderter Haut. Arch. Kin. exp. Derm., 1954, 198, 111-198.

4) Braun-Falco, 0 . Uber die Fähigkeit der menschlichen Haut zur Polysaccharidsynthese, ein Beitrag zur Histotopochemie der Phosphorylase. Arch. klin. exp. Derm., 1956, 202, $163-170$

5) Ellis, R.A.\& Montagna, W. Histology and cytochemistry of human skin. XV. Sites of phosphorylase and amylo-1,6-glucosidase activity. J."Histochem. Cytochem., 1958, 6, 201-207.

B) Goltz, R.W., Fusaro, R.M., Blazejovsky, R. \& Jarvis, J. Pathways of carbohydrate metabolism in normal and neoplastic cutaneous ectoderm, a histochemical study. $J$. invest. Derm., 1959, 33, 337-345.

7) Wells, G.C., Sanderson, K.V. \& MaCabe, I.M. The histochemical localization of phosphorylases in skin. Brit. J. Derm., 1961, 73, 337-345.

8) Sasai, Y. Histochemical demonstration of phosphorylase a, phosphorylase $b$ and phosphorylase kinase in normal human skin, Tohoku J.exp. Med., 1965, 85, 160-170.

9) Takeuchi, T. \& Glenner, G.G. Histochemical demonstration of a pathway for polysaccharide synthesis from uridine diphosphoglucose. J. Histochem. Cytochem., 1960, $8,227-230$.

10) Wegmann, R., Verne, J. \& Guha, S. Activité de l'uridine diphosphoglucose-glycogène transferase dans le muscle. Anл. Histochim., 1960, 5, 253-258.

11) Takeuchi, T. \& Kuriaki, H. Histochemical demonstration of phosphorylase in animal tissues. J. Histochem. Cytochem., 1955, 3, 153-160.

12) Takeuchi, T. \& Glenner, G.G. Histochemical demonstration of uridine diphosphate glucose-glycogen transferase in animal tissues. J. Histochem. Cytochem., 1961, 9, 304316.

13) Halprin, K.M. \& Ohkawara, A. Glucose and glycogen metabolism in the human epidermis. J. invest. Derm., 1966, 46, 43-50. 
14) Rosell-Perez, M., Villar-Palasi, C. \& Larner, J. Studies on UDPG-glycogen trans. glucosylase. I. Preparation and differentiation of two activities of UDPG-glycogen transglucosylase from rat skeletal muscle. Biochemistry, 1962, 1, 763-768.

15) Rosell-Perez, M. \& Larner, J. Studies on UDPG-a-glucan transglucosylase. V. Two forms of the enzyme in dog skeletal muscle and their interconversion. Biochemistry, $1964,3,81-88$.

16) Steiner, D.F., Younger, L. \& King, J. Purification and properties of uridine diphosphate glucose-glycogen glucosyltransferase from rat liver. Biochemistry, 1965, 4, 740751 . 